\title{
Catharanthus roseus Genes Regulated Differentially by Mollicute Infections
}

\author{
Sandrine Jagoueix-Eveillard, Frank Tarendeau, Karine Guolter, Jean-Luc Danet, Joseph M. Bové, \\ and Monique Garnier \\ Laboratoire de Biologie Cellulaire et Moléculaire, Institut de Biologie Végétale Moléculaire INRA \& \\ Université Victor Ségalen Bordeaux 2, BP 81, 33883 Villenave d'Ornon cedex, France \\ Accepted 21 October 2000.
}

\begin{abstract}
A differential display of mRNAs was used to isolate periwinkle cDNAs differentially expressed following infection with one of three mollicutes: Spiroplasma citri, Candidatus Phytoplasma aurantifolia, and stolbur phytoplasma. Twenty-four differentially expressed cDNAs were characterized by Northern blots and sequence analysis. Eight of them had homologies with genes in databanks coding for proteins involved in photosynthesis, sugar transport, response to stress, or pathways of phytosterol synthesis. The regulation of these genes in periwinkle plants infected by additional phloemrestricted bacteria showed that they were not specific to a given mollicute, but correlations with particular symptoms could be established. Expression of transketolase was down regulated following infection with a pathogenic strain of $S$. citri. No down regulation was observed for the nonphytopathogenic mutant GMT553, which is deficient for fructose utilization.
\end{abstract}

Mollicutes are an important group of plant pathogens that are responsible for hundreds of diseases worldwide (McCoy et al. 1989). They are localized exclusively in the phloem sieve tubes and transmitted by phloem-sap-feeding insects such as leafhoppers or psyllids. Two groups of plant-pathogenic mollicutes are Spiroplasma spp., which can be cultured in artificial media (Saglio et al. 1971); and Candidatus Phytoplasma spp., which have, so far, resisted in vitro cultivation (Seemüller et al. 1998). Most spiroplasmas and phytoplasmas can be transmitted to periwinkle plants (Catharanthus roseus) via dodder (Cuscuta spp.), a parasitic phloem-feeding plant, or via their respective insect vectors. Within periwinkle plants, spiroplasmas and phytoplasmas induce disorders similar to those observed in their original host plant such as leaf yellowing, growth aberrations (proliferations, internode shortening, stunting), flower malformations, and/or decline. The mechanisms involved in symptom development are unknown and, currently, the mollicute interactions with their host plants are poorly understood.

The most studied phytopathogenic mollicute is Spiroplasma citri because it was the first of the three plant pathogenic spiroplasmas to be cultured and characterized (Saglio et al.

Corresponding author: M. Garnier Telephone: +33 5568431 49; Fax: +33 5568431 59; E-mail: garnier@bordeaux.inra.fr
1973). Viral and artificial plasmid vectors have been developed for gene cloning and expression in the spiroplasmas (Renaudin and Bové 1995; Ye et al. 1994). Transposon Tn4001 mutagenesis could be applied to $S$. citri, resulting in the identification of GMT 553, a mutant that is weakly pathogenic (Foissac et al. 1997) and unable to use fructose (Gaurivaud et al. 2000b). Fructose utilization by the wild-type spiroplasma was correlated with symptom expression (Gaurivaud et al. 2000a).

As no phytoplasma cultures are available, studies on phytoplasma interactions with host plants are limited and genetic approaches cannot be envisaged. Phytoplasmainduced modifications of phloem structure and biochemical disturbance of phloem functions have been reported (Lepka et al. 1999; McCoy 1979). The differential display (DD) technique (Liang and Pardee 1992), which allows identification and isolation of eukaryotic cDNAs expressed differentially under various conditions, has been used extensively by animal and plant physiologists to study gene expression during development and recently has been applied to the study of plant-pathogen interactions (Benito et al. 1996; Mareyrat et al. 1998; Seehaus and Tenhaken 1998; Truesdell and Dickman 1997). In the case of phytoplasmas, only one attempt to isolate genes involved in plant-phytoplasma interactions has been reported (Smart and Kirkpatrick 1996), but apparently has not been pursued.

Here we describe for the first time the use of the DD method to identify genes that are up or down regulated in periwinkle plants following infection by one of three mollicutes: Spiroplasma citri; stolbur phytoplasma (Fos et al. 1992; McCoy 1989), which induces leaf yellows, internode shortening, and flower aberrations in periwinkle and many other plants; and Candidatus Phytoplasma aurantifolia, the agent of witches' broom disease of lime (WDBL) that is responsible for spectacular proliferations and witches' broom in Citrus spp. and periwinkle plants (Garnier et al. 1991; Zreik et al. 1995).

The periwinkle genes differentially displayed after infection with the above three mollicutes also were studied in periwinkle plants infected with various other phytoplasmas or phloem-restricted proteobacteria. Expression of a transketolase gene in plants infected by the pathogenic GII-3 strain of S. citri or the weakly pathogenic mutant GMT 553 (Foissac et al. 1997; Gaurivaud et al. 2000a; Gaurivaud et al. 2000b) also is described. 


\section{MATERIALS AND METHODS}

\section{Bacterial strains.}

The cultivable mollicute $S$. citri (Saglio et al. 1973) and several phloem-restricted uncultured bacteria were used in this study (Bové et al. 1998). They were maintained in periwinkle plants, grown in an insect-proof greenhouse, and propagated by grafting. Additionally, they consisted of the phytoplasmas responsible for aster yellows (AY), apple proliferation (AP), stolbur phytoplasma (Mc Coy et al. 1979), Candidatus Phytoplasma aurantifolia, the WBDL agent (Garnier et al. 1991; Zreik et al. 1995), and the alpha-proteobacterium Candidatus Liberibacter sp. that is responsible for citrus Huanglongbing disease (Jagoueix et al. 1994). Symptoms induced by these pathogens are yellowing and stunting (S. citri, stolbur phytoplasma, Candidatus Liberibacter sp.), yellowing and proliferation (AY), and pale-green leaves and proliferation (Candidatus Phytoplasma aurantifolia, apple proliferation).

The leafhopper-transmissible strains GII3 (phytopathogenic) and GMT553 (nonphytopathogenic) of S. citri (Foissac et al. 1997) also were used in this work. Plants infected with S. citri, Candidatus Phytoplasma aurantifolia, and Candidatus Liberibacter sp. were grown at $30^{\circ} \mathrm{C}$ during the day and $25^{\circ} \mathrm{C}$ at night. Plants infected with the other phytoplasmas were grown at $25^{\circ} \mathrm{C}$ during the day and $20^{\circ} \mathrm{C}$ at night.

\section{Inoculation of $S$. citri to periwinkle plants.}

Healthy periwinkle plants were grown from seeds in an insect-proof greenhouse at $30^{\circ} \mathrm{C}$. When they had four to six leaves, either 10 healthy or S. citri-infected Circulifer haematoceps were put on each plant, as described in Foissac et al. (1997). After 12 days, the insects were removed. Leaves for RNA isolation were taken at different times after insect removal, until plants showed well-developed symptoms.

Differential display (DD) of mRNA was performed with RNA extracted from healthy and infected plants 50 to 60 days after inoculation when infected plants showed well-developed symptoms.

\section{Transmission of the uncultured phloem-restricted bacteria to periwinkle plants.}

The uncultured phytoplasmas and Candidatus Liberibacter asiaticus were transmitted to periwinkle plants by graft inoculation. For DD analysis, samples were taken when characteristic symptoms were observed approximately 6 weeks after grafting. As controls, healthy plants were grafted similarly with uninfected $C$. roseus shoots.

\section{RNA isolation.}

RNA was isolated according to Puissant and Houdeline (1990). Leaf midribs (0.3 to $0.9 \mathrm{mg}$ ) were ground in mortar with liquid nitrogen and the resulting powder was transferred into a glass tube. Five milliliters of extraction buffer (4 M guanidinium isothiocyanate, $25 \mathrm{mM}$ sodium citrate, $0.5 \%$ sarkosyl, 0.1 M beta mercaptoethanol) were added. The sample was further ground for $30 \mathrm{~s}$ with a type PT 10/35 polytron (Kinematica, Littau-Luzern, Switzerland) and transferred to a 12-ml tube. A volume of $0.5 \mathrm{ml}$ of $2 \mathrm{M}$ sodium acetate, $\mathrm{pH} 4$, $5 \mathrm{ml}$ of water-saturated phenol, and $1 \mathrm{ml}$ of chloroform were added. The tube was vortexed and centrifuged for $10 \mathrm{~min}$ at $10,000 \times g$. Nucleic acids were precipitated from the aqueous phase by isopropanol for $1 \mathrm{~h}$ at $-20^{\circ} \mathrm{C}$. The sample was then centrifuged for $10 \mathrm{~min}$ at $10,000 \times g$, the pellet was resuspended in $1.5 \mathrm{ml}$ of $4 \mathrm{M} \mathrm{LiCl}$, transferred to an Eppendorf tube and vortexed for 10 to $30 \mathrm{~min}$. The tube was centrifuged for $10 \mathrm{~min}$ and the pellet was resuspended in $1 \mathrm{ml}$ of $4 \mathrm{M}$ $\mathrm{LiCl}$, following the same procedure as above. After centrifugation for $10 \mathrm{~min}$, the pellet was resuspended in $500 \mu \mathrm{l}$ of Tris $10 \mathrm{mM}, \mathrm{pH} 7.5,0.5 \%$ sodium dodecyl sulfate (SDS), and 1 $\mathrm{mM}$ EDTA and alternately submitted to $10 \mathrm{~min}$ of vortexing and $10 \mathrm{~min}$ of incubations at $65^{\circ} \mathrm{C}$, until complete dissolution.

The sample was extracted once with Tris-saturated-phenol and twice with chloroform. Seventy milliliters of $2 \mathrm{M}$ sodium acetate, $\mathrm{pH} \mathrm{5}$, and $700 \mu \mathrm{l}$ of isopropanol were added to the last aqueous phase and incubated for $1 \mathrm{~h}$ at $-20^{\circ} \mathrm{C}$. After a centrifugation for $15 \mathrm{~min}$ at $10,000 \times g$, the pellet was dried and suspended in $70 \mu \mathrm{l}$ of water. Subsequently, the RNA sample was treated with RQ1 DNase to remove residual DNA, following the protocol described by the manufacturer (Promega, Madison, WI, U.S.A.).

\section{Differential display.}

cDNAs were synthesized with the RNAimage Kit (GenHunter Corp., Brooklin, MA, U.S.A.) from $0.4 \mu \mathrm{g}$ of DNA-free RNA for $60 \mathrm{~min}$ at $37^{\circ} \mathrm{C}$, Malonay Murine Leukemia Virus reverse transcriptase, and reverse transcription (RT) primers $\mathrm{H}_{-} \mathrm{T}_{11} \mathrm{M}$ ( $\mathrm{H}$ corresponds to the HindIII restriction site and $\mathrm{M}$ is either deoxyadenosine, deoxyguanosine, or deoxycytidine. Template and primers were denatured for $5 \mathrm{~min}$ at $65^{\circ} \mathrm{C}$ prior to the reaction.

The reaction was heat inactivated for $15 \mathrm{~min}$ at $75^{\circ} \mathrm{C}$, and one-tenth of each sample was amplified by polymerase chain reaction (PCR), following the manufacturer's instructions, combining the primer used for reverse transcription with arbitrary primers. PCR conditions were $94^{\circ} \mathrm{C}$ for $30 \mathrm{~s}, 38^{\circ} \mathrm{C}$ for 60 $\mathrm{s}$, and $72^{\circ} \mathrm{C}$ for $90 \mathrm{~s}$ for 40 cycles, followed by 7 min elongation at $72^{\circ} \mathrm{C}$. Three microliters of the amplified DNA were heated for $3 \mathrm{~min}$ at $90^{\circ} \mathrm{C}$ with $2 \mu \mathrm{l}$ of loading dye (95\% formamide, $20 \mathrm{mM}$ EDTA, $0.05 \%$ bromophenol blue, $0.05 \%$ xylene cyanol) and separated by electrophoresis on a $6 \%$ denaturing polyacrylamide gel. The gel was then vacuum dried at $80^{\circ} \mathrm{C}$ for $90 \mathrm{~min}$ and exposed to X-ray films overnight. Each reaction was performed at least twice to prevent the selection of false differentially expressed bands.

Differentially displayed DNA bands were excised and eluted from the gel by incubation with $50 \mu \mathrm{l}$ of water for $2 \mathrm{~h}$ at $56^{\circ} \mathrm{C}$. Four microliters were used for DNA amplification by PCR, as described above, with $20 \mu \mathrm{M}$ deoxynucleoside triphosphates (dNTP) instead of $2 \mu \mathrm{M}$. DNA was analyzed on $0.7 \%$ agarose gels, and the bands at the expected size were excised and purified with the Clean-Mix Kit (Talent, Trieste, Italy). The DNA was cloned in the pGEM-T Easy Vector (Promega), following the manufacturer's instructions.

\section{Northern blot analysis.}

Approximately $10 \mu \mathrm{g}$ of total RNAs were separated on $1 \%$ agarose gel containing 3\% formaldehyde, $8.8 \%$ morpholinepropanesulfonic acid (MOPS), and $0.15 \mu \mathrm{g}$ of ethidium bromide per ml. RNA samples were treated prior to loading with $47 \%$ formamide, $18 \%$ formaldehyde, and 9.5\% MOPS, and incubated for $10 \mathrm{~min}$ at $65^{\circ} \mathrm{C}$. One microliter of loading dye was added. 
The RNAs were transferred to Hybond C extra (Amersham Corp., Arlington Heights, IL, U.S.A.) membranes in 10× SSC $\left(1.5 \mathrm{M} \mathrm{NaCl}\right.$ plus $0.15 \mathrm{M}$ sodium citrate) and dried at $80^{\circ} \mathrm{C}$ for $2 \mathrm{~h}$.

Prehybridization was performed at $42^{\circ} \mathrm{C}$ in a solution containing $5 \times \mathrm{SSC} ; 50 \%$ formamide; $0.5 \%$ SDS; $5 \times$ Denhardt; $0.02 \mathrm{M}$ Tris, $\mathrm{pH} 7.5$; and $0.3 \mathrm{mg}$ of yeast RNA per ml.

Hybridization was performed in the same buffer containing alpha- ${ }^{32} \mathrm{PdATP}-$ labeled probes obtained from the pGEM-T easy vectors.

Membranes were washed three times for 10 min with $2 \times$ SSC and $0.5 \%$ SDS at room temperature, then with $0.1 \times$ SSC and $0.1 \% \mathrm{SDS}$ at $50^{\circ} \mathrm{C}$ for $45 \mathrm{~min}$ before exposure to $\mathrm{X}$-ray films.

\section{Isolation of the transketolase gene $(Q)$ by RT-PCR.}

Ten micrograms of RNA from healthy periwinkle plants were mixed with $4 \mu \mathrm{l}$ of $5 \mu \mathrm{M}$ Q2 primer $\left(5^{\prime}-\right.$ TCATGAACCACCTGATC- $3^{\prime}$ ), defined at the $5^{\prime}$ end of the Q cDNA, heated $10 \mathrm{~min}$ at $75^{\circ} \mathrm{C}$, and immediately put on ice. Five microliters of $5 \times$ buffer (Promega), $2 \mu$ of DTT, $2 \mu$ of $200 \mu \mathrm{M} d \mathrm{dTPs}$, and $1 \mu \mathrm{l}$ of MMLV reverse transcriptase were added, and the tube was incubated for 90 minutes at $37^{\circ} \mathrm{C}$. The enzyme was heat inactivated for $10 \mathrm{~min}$ at $70^{\circ} \mathrm{C}$. The PCR was done following the same protocol as that of the differential display PCR with primers Q2 and Q1 (5'AACTACCCAATCCACATGAA-3') defined in a consensus $3^{\prime}$ end sequence of Oriza sativa AF024512 and Arabidopsis thaliana Y14333 transketolase sequences.

\section{DNA sequencing and analysis.}

Clones were sequenced with the $\mathrm{T} 7$ sequencing kit (Pharmacia, Uppsala, Sweden). Sequences were compared with those from the National Center for Biotechnology Information (NCBI) databases with the Basic Local Alignment Search Tool (BLAST) algorithm. Multiple sequence alignments were performed by CLUSTAL and MAP algorithms.

\section{RESULTS}

\section{Identification of mRNA differentially expressed in periwinkle plants following infection with mollicutes.}

Plant RNA was submitted to reverse transcription and the DNA obtained was amplified by PCR, yielding cDNAs. The cDNAs from healthy periwinkle plants were compared on polyacrylamide gels with those obtained from periwinkle plants infected either by $S$. citri, the stolbur phytoplasma, or Candidatus Phytoplasma aurantifolia. Approximately 80 bands were seen on each lane of the gels, and the amplified products were 100 to $1,200 \mathrm{bp}$. Figure 1 illustrates an area of a polyacrylamide gel where a band (arrow) that was prominent in the profiles from healthy periwinkle plants (lanes 1 and 2) was faint in those infected with $S$. citri (lanes 3 and 4).

Seventeen differentially expressed DNA bands were selected following infection by $S$. citri and 26 and 23 bands following infection with the stolbur and WBDL phytoplasmas, respectively, totaling 66 bands. The selected bands were cut out of the dried polyacrylamide gel and the DNAs were eluted, reamplified with the same primer combinations, and cloned for sequence determination and verification of the differential expression by Northern blots.
Of the 66 bands, only one could not be reamplified, whereas 38 bands have so far been analyzed. Four bands gave no hybridization signals and nine bands yielded equivalent signals with RNAs extracted from healthy and infected periwinkle plants, thus corresponding to false positives. The results obtained from the currently analyzed bands are summarized in Table 1 and Northern blots for 14 bands are shown in Figure 2. Northern blots agreed with the differential display gels for all the bands tested, except band $\mathrm{J}$, which was isolated in the case of $S$. citri infection. Band $\mathrm{J}$ also appeared to be up regulated on the gel, but hybridization revealed very strong signals with RNAs extracted only from healthy periwinkle plants, showing that it corresponded to a down-regulated gene. All three pathogens resulted in the obtention of up- and downregulated genes. Until now, however, a majority of bands corresponded to down-regulated genes, in the case of $S$. citri and stolbur phytoplasma, whereas the predominance of upregulated genes was found in periwinkle plants infected with Candidatus Phytoplasma aurantifolia.

\section{Sequence analysis of the cDNA clones.}

The nucleotide sequences of 24 cDNA clones were determined and compared with those in databanks to reveal putative homologies. Sixteen of them did not show homology with known proteins. In particular, none of the bands analyzed from Candidatus Phytoplasma aurantifolia-infected periwinkle plants had equivalents in the databanks. On the contrary, DNA from bands I, Q, C1, A11-1, C9-1 and G17-4, isolated

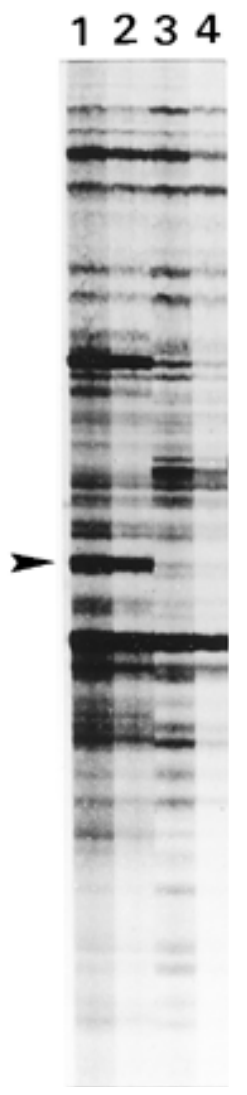

Fig. 1. Polyacrylamide gel electrophoresis of cDNA isolated from healthy (lanes 1 and 2) or Spiroplasma citri-infected (lanes 3 and 4) periwinkle plants. Arrow shows a differentially expressed cDNA. 
from S. citri-infected periwinkle plants, had strong homologies with previously sequenced protein genes. Band I showed strong homology in its derived amino-acid sequence (68 amino acids) with sterol-C-methyltransferase from Synechocystis sp. and A. thaliana. This enzyme is involved in the synthesis of phytosterols, which play multiple roles in plant growth and development as they are precursors of steroid growth regulators (Haughan et al. 1988; Shi et al. 1996). The putative product of band Q had a strong homology (70\% identity, $80 \%$ similarity) with a transketolase-like protein from O. sativa (AF024512), an enzyme involved in sugar transport (Bernacchia et al. 1995). In plants, transketolases also play important roles in the Calvin cycle, catalyzing two reactions for the regeneration of ribulose-1-5-biphosphate (Lange et al. 1998). The band C1-deduced protein had homology with a wall-associated kinase (He et al. 1999), A11-1 product with a desiccation protectant protein (Maitra and Cushman 1994) and the G17-4 protein with a chlorophyll a/b binding protein (Falconet et al. 1993). Homology with a gene of unknown function also was evidenced (band C9-1). In the stolbur phytoplasma infection, two of the repressed bands (C2 and Z1) had homologies with genes involved in photosynthesis (subunit III of photosystem I and ribulose 1,5-biphosphate carboxylase-oxygenase).

\section{Specificity of the selected bands.}

The bands we selected were isolated from periwinkle plants at late stages of infection when severe symptoms were observed on the plants. Leaf yellows and stunting are induced by many, but not all, phloem-restricted plant mollicutes or walled-bacteria. Thus, these symptoms are not highly specific, and it is likely that the down regulation of some of the genes we identified, particularly those involved in photosynthesis, also occurs with other pathogens. This was verified for bands Q, I, Z1, and PaB1 on Northern blots with RNAs extracted from periwinkle plants infected with one of various phloemrestricted bacteria. Table 2 and Figure 3 show that none of the four genes were regulated specifically by a given mollicute. Gene Q (transketolase) (Fig. 3, first panel) was down regulated in periwinkle plants showing strong leaf yellows whether they had proliferation (aster yellows) or not (S. citri, stolbur, Candidatus Liberibacter sp.), but down regulation was much less in plants showing proliferations without severe leaf yellows (apple proliferation and WBDL). In contrast, gene I (Fig. 3, second panel) coding for a putative sterol-Cmethyltransferase was down regulated in periwinkle plants showing leaf yellows and stunting, but did not appear in those with proliferations. Gene Z1 (ribulose 1,5-biphosphate carboxylase-oxygenase) (Fig. 3, third panel) was down regulated in plants with strong yellowing, whereas gene $\mathrm{PaB} 1$, which was activated in Candidatus Phytoplasma aurantifoliainfected periwinkle plants, also was activated by the apple proliferation phytoplasma.

\section{Expression of the transketolase-like mRNA following infection of periwinkle plants.}

Gene Q, which showed homologies with transketolase, an enzyme involved in sugar transport, was studied further, particularly because the weakly pathogenic mutant GMT 553 of $S$. citri is defective in fructose utilization (Gaurivaud et al. 2000a; Gaurivaud et al. 2000b). The homology of the Q fragment with a transketolase gene was confirmed by isolating a larger DNA fragment by RT-PCR, as described above. A sequence of 2,087 bp was obtained, corresponding to 673 amino acids, or approximately $90 \%$ of the transketolase protein. Figure 4 shows the multiple sequence alignment of the amino

Table 1. Differential display and sequencing results

\begin{tabular}{|c|c|c|c|c|}
\hline Bands & Primer combinations & Infecting mollicutes & Northern blots results & GenBank homologies \\
\hline $\mathrm{I}$ & T11GC-U2 & Spiroplasma citri & $\mathrm{R}^{\mathrm{a}}$ & Delta-C-methyltransferase \\
\hline $\mathrm{J}$ & $\mathrm{Id}^{\mathrm{b}}$ & S. citri & $\mathrm{R}$ & $\mathrm{N}^{\mathrm{c}}$ \\
\hline M & Id & S. citri & $A^{d}$ & $\mathrm{~N}$ \\
\hline Q & T11CC-U2 & S. citri & $\mathrm{R}$ & Transketolase \\
\hline B1 & T11A-9 & S. citri & $\mathrm{R}$ & $\mathrm{N}$ \\
\hline $\mathrm{C} 1$ & $\mathrm{~T} 11 \mathrm{~A}-11$ & S. citri & A & Wall-associated kinase \\
\hline $\mathrm{C} 5$ & $\mathrm{~T} 11 \mathrm{G}-3$ & S. citri & $\mathrm{R}$ & $\mathrm{N}$ \\
\hline A9-1 & $\mathrm{T} 11 \mathrm{~A}-9$ & S. citri & $\mathrm{R}$ & $\mathrm{N}$ \\
\hline A11-1 & $\mathrm{T} 11 \mathrm{~A}-1$ & S. citri & $\mathrm{R}$ & Desiccation protectant \\
\hline C9-1 & $\mathrm{T} 11 \mathrm{C}-1$ & S. citri & $\mathrm{R}$ & Unknown Arabidopsis thaliana \\
\hline C9-12 & T11C-9 & S. citri & A & $\mathrm{N}$ \\
\hline A13-4 & $\mathrm{T} 11 \mathrm{~A}-13$ & S. citri & $\mathrm{R}$ & $\mathrm{N}$ \\
\hline G17-4 & $\mathrm{T} 11 \mathrm{G}-17$ & S. citri & $\mathrm{R}$ & Chlorophyll $\mathrm{a}-\mathrm{b}$ binding protein \\
\hline $\mathrm{PaB} 1$ & $\mathrm{~T} 11 \mathrm{~A}-2$ & Candidatus Phytoplasma aurantifolia & A & $\mathrm{N}$ \\
\hline $\mathrm{C} 1$ & Id & Candidatus Phytoplasma aurantifolia & A & $\mathrm{N}$ \\
\hline $\mathrm{J} 2$ & Id & Candidatus Phytoplasma aurantifolia & A & $\mathrm{N}$ \\
\hline $\mathrm{X} 2$ & T11A-6 & Candidatus Phytoplasma aurantifolia & $\mathrm{R}$ & $\mathrm{N}$ \\
\hline $\mathrm{T} 1$ & Id & Candidatus Phytoplasma aurantifolia & A & $\mathrm{N}$ \\
\hline U3 & Id & Candidatus Phytoplasma aurantifolia & A & $\mathrm{N}$ \\
\hline $\mathrm{C} 2$ & $\mathrm{~T} 11 \mathrm{C}-1$ & Stolbur Phytoplasma & $\mathrm{R}$ & Subunit III of photosystem I \\
\hline A1 & $\mathrm{T} 11 \mathrm{C}-1$ & Stolbur Phytoplasma & $\mathrm{A}$ & $\mathrm{N}$ \\
\hline $\mathrm{Z1}$ & T11C-6 & Stolbur Phytoplasma & $\mathrm{R}$ & $\begin{array}{l}\text { Ribulose } 1,5 \text {-biphosphate carboxylase- } \\
\text { oxygenase }\end{array}$ \\
\hline $\mathrm{F} 1$ & $\mathrm{~T} 11 \mathrm{C}-1$ & Stolbur Phytoplasma & $\mathrm{R}$ & $\mathrm{N}$ \\
\hline $\mathrm{H} 2$ & $\mathrm{~T} 11 \mathrm{C}-2$ & Stolbur Phytoplasma & $\mathrm{R}$ & $\mathrm{N}$ \\
\hline
\end{tabular}

\footnotetext{
${ }^{a}$ Repressed.

b Idem.

c No homology.

d Activated.
} 
acid sequence deduced from the periwinkle transketolase-like gene with four transketolase or transketolase-like amino acid sequences: Craterostigma plantagineum (Z46648), Solanum tuberosum (Z50099), A. thaliana (Y14333), and O. sativa (AF024512). A similarity of $83 \%$ was observed with the transketolase from A. thaliana. Out of 50 invariant residues, as defined by Schenck et al. 1997 (underlined bold letters), 27

A

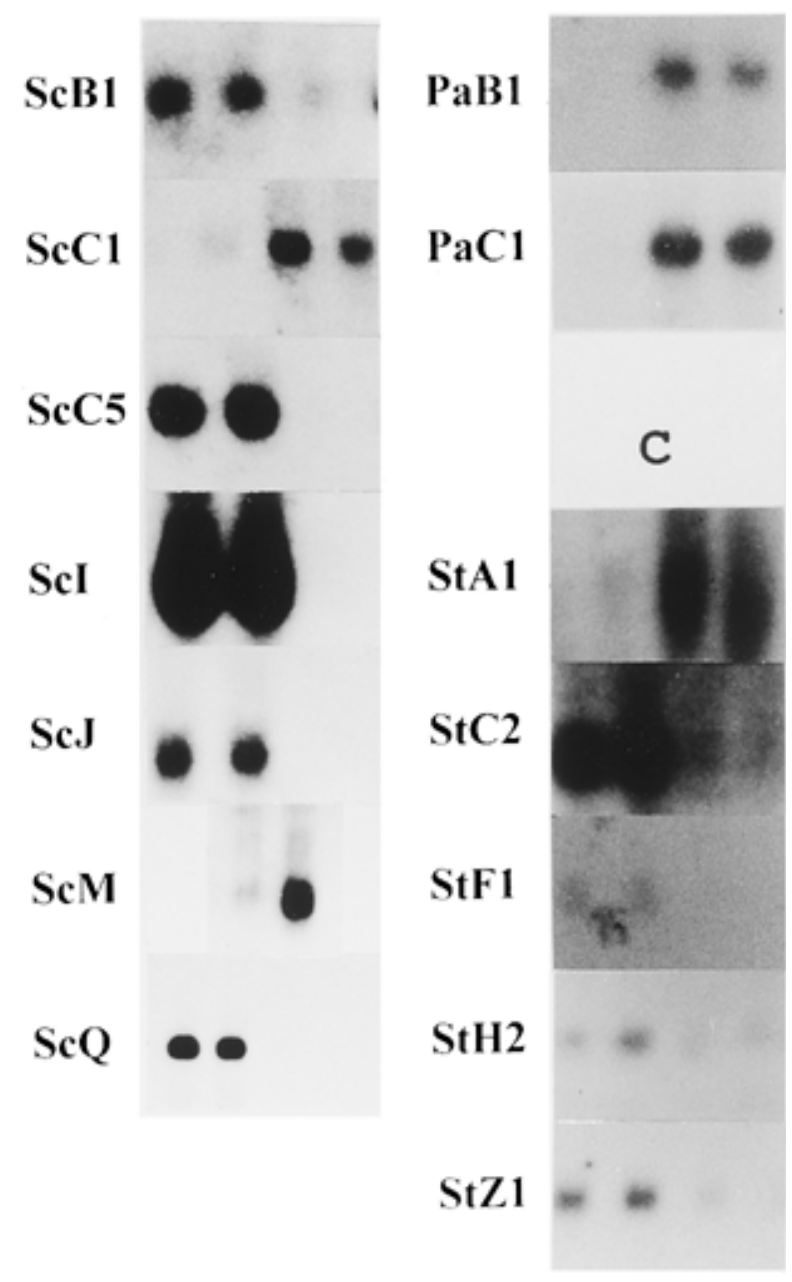

Fig. 2. Northern blot hybridizations of RNAs extracted from infected periwinkle plants with ${ }^{32} \mathrm{P}-l a b e l e d ~ c D N A$. Healthy (first two lanes), Spiroplasma citri (A, last two lanes), Candidatus Phytoplasma aurantifolia (B, last two lanes), or stolbur phytoplasma (C, last two lanes). One healthy lane and one infected lane are shown for ScM. were present in the periwinkle transketolase sequence. The thiamin pyrophosphate (TPP) binding motif (cofactor) and the transketolase motif (Schenk et al. 1997) also were identified.

The expression of the periwinkle transketolase mRNA following infection by the wild-type GII3 strain or the GMT 553 mutant of S. citri was studied on Northern blots of RNAs extracted at various times after infection. The outline of the experiment is given in Table 3 and Northern blots in Figure 5. The data showed that the transketolase gene was weakly expressed only in very young (4 weeks old) periwinkle plants at the time when healthy or $S$. citri-infected leafhoppers were put on the plant (lane 0). After a 12-day transmission period, the leafhoppers were removed and the gene was found to be strongly expressed in plants inoculated with the phytopathogenic strain GII3 (Fig. 5A, lane 1) or the weakly pathogenic mutant GMT 553 (Fig. 5A, lane 1'). Control plants that received no insects had the same pattern of transketolase gene expression (data not shown). The presence of spiroplasmas in the inoculated plants was followed by hybridization on Northern blots probed with a gene coding for a constitutive membrane protein of the spiroplasma spiralin (Bové et al. 1993) (Fig. 5B). No spiroplasmas could be detected in the plants when the insects were removed (Fig. 5B, lanes 1 and $1^{\prime}$ ). At day 22, when faint symptoms were observed on the periwinkle plants inoculated with the wild-type strain spiroplasma (Table 3 ), down regulation of the transketolase gene was observed and a strong spiralin signal was present (Fig. 5A and B, lane 2). Expression of the transketolase gene was totally abolished after day 22 and symptom severity increased, whereas the spiroplasma titer remained constant (Fig. 5A and B, lanes 3 to $6)$. In the case of periwinkle plants infected with the nonpathogenic mutant GMT 553, expression of the transketolase gene remained unaffected up to 56 days postinoculation (Fig. $5 \mathrm{~A}$, lanes $2^{\prime}$ to $7^{\prime}$ ). This correlated with a low spiroplasma titer in the plants from day 22 to 47 (Fig 5B, lanes $2^{\prime}$ to $5^{\prime}$ ). Forty-nine days after the transmission period, symptoms started to develop in agreement with the increase of the spiroplasma titer, but the transketolase gene expression remained unmodified up to 56 days posttransmission. From there on, however, as was the case with the wild-type spiroplasma, expression of the transketolase gene was abolished (Fig. 5A, lanes $8^{\prime}$ and $9^{\prime}$ ). Previously it was shown that symptom development in infected periwinkle plants occurs when the spiroplasma titer reaches $10^{6}$ to $10^{7}$ organisms per $200 \mathrm{mg}$ of leaf midribs (Foissac et al. 1997). In plants infected with the mutant strain, this titer is reached much later than it does in plants infected with the wild-type strain because the wild-type spiroplasma has a multiplication rate that is higher than the mutant. When the titer of the $S$. citri mutant is high, however,

Table 2. Gene expression in periwinkle plants infected with various phloem-restricted bacteria

\begin{tabular}{lccccccc}
\hline & \multicolumn{7}{c}{ Periwinkle infections } \\
\cline { 2 - 8 } Probes & None & $\begin{array}{c}\text { Aster yellows } \\
\text { phytoplasma }\end{array}$ & Spiroplasma citri & Liberibacter sp. & $\begin{array}{c}\text { Apple proliferation } \\
\text { phytoplasma }\end{array}$ & $\begin{array}{c}\text { Stolbur phy- } \\
\text { toplasma }\end{array}$ & $\begin{array}{c}\text { Candidatus } \\
\text { Phytoplasma aurantifolia }\end{array}$ \\
\hline $\mathrm{Q}$ & $+^{\mathrm{a}}$ & $-^{\mathrm{b}}$ & - & - & + & - & + \\
$\mathrm{I}$ & + & + & - & - & + & + & + \\
$\mathrm{Z} 1$ & + & - & - & - & + & + & + \\
$\mathrm{PaB} 1$ & - & - & - & - & + & + \\
\hline
\end{tabular}

${ }^{a}$ Hybridization signal.

${ }^{\mathrm{b}}$ No or faint hybridization signal. 
transketolase is not repressed (Fig. 5B, lanes $6^{\prime}$ and $7^{\prime}$ ). In addition, it was shown that after 8 weeks in the plant, reversion of GMT 553 to the wild-type phenotype spiroplasmas occurs and is correlated with symptom development (Foissac et al. 1997; Gaurivaud et al. 2000a). This also is in agreement with the down regulation of the transketolase gene (Fig. 5A, lanes $8^{\prime}$ and $9^{\prime}$ ).

\section{DISCUSSION}

The mechanisms involved in the pathogenicity of plant mollicutes are beginning to be studied. As most of these plant pathogens are not available in culture, we used the DD method to identify genes whose expression is modified following infection. The host plant chosen for this approach was periwinkle because it is used worldwide for mollicute maintenance and studies because mollicutes reach high titers in this species. Our results demonstrate that the DD methodology is suitable to study plant-mollicute interactions, even though, as reported by others, up to $30 \%$ of the bands were false positives. With the use of a limited number of primer combinations, we isolated and characterized 24 cDNA clones corresponding to mRNAs that are up or down regulated in periwinkle plants following infection with phytopathogenic mollicutes. Twenty-eight additional differentially expressed bands remain to be studied. Only one of the bands, band J, which appeared up regulated on the gel, turned out to correspond to a down-regulated gene after hybridization. Certainly this is because several genes were present in the band recovered from the DD gel and the clone selected for hybridization was representative of one part of the population.

Because the DNA sequences obtained from the DD gels were short and corresponded to the 3 '-untranslated sequence, we were only able to identify similarities with genes in the databases for eight of the DNA clones. Screening of genomic and cDNA libraries are under way to isolate the entire genes in order to increase the chances to identify orthologs in databanks. PCR amplification of most of the putative transketolase gene of periwinkle allowed us to find the characteristic motifs of this enzyme and confirm the homology initially found with transketolases from other plant species.

For the first time, we have shown that a gene coding for a pathogen-induced protein, namely a wall associated kinase (He et al. 1999), was activated by S. citri infection. In Arabidopsis spp., this gene also is induced by salicylic acid and is involved in the plant's defense response. At this stage, no function could be assigned to the other up-regulated genes that we detected. It is worth noting that most of the up-regulated genes identified were from plants infected with Candidatus Phytoplasma aurantifolia, which induces abundant witches' broom proliferations, an active developmental process compared with leaf yellows and stunting.

The genes we isolated were from late-infection stages and concerned several metabolic pathways. They were not specific to a given phloem-restricted bacterium but, even though the number of pathogens of each symptom type was small, we could associate the regulation of some of the genes with the type of symptoms observed on the plant.

Indeed, sugars seem to play an important role in the pathogenicity of certain mollicutes. Fructose utilization by $S$. citri is a key factor for symptom development (Gaurivaud et al. 2000a). Lepka et al. (1999), showed that infection of tobacco or periwinkle plants with various phytoplasmas results in a marked increase of soluble carbohydrates in source leaves and lower levels of carbohydrates in sink organs. Thus, it has now been proposed that $S$. citri competes with the companion cells for fructose utilization and impairs sucrose loading by the

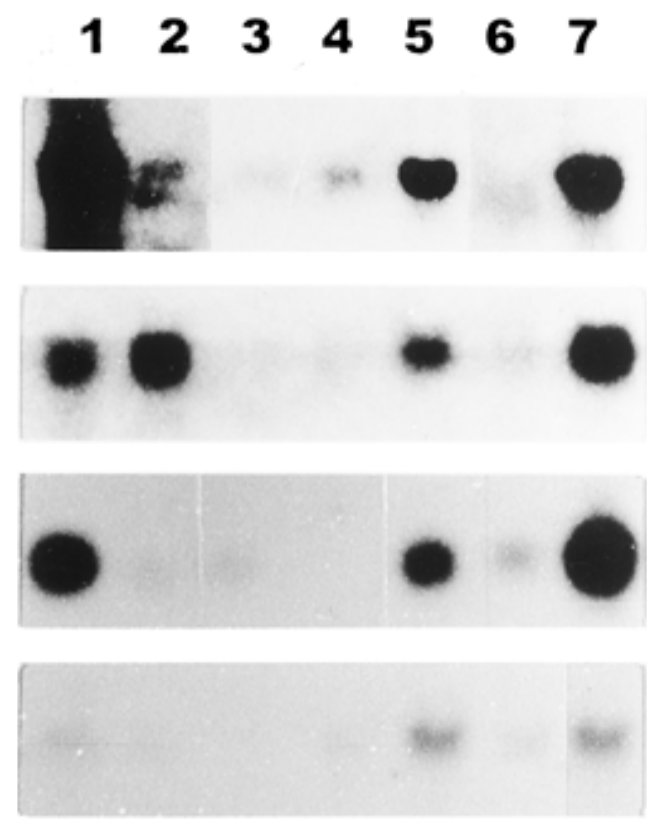

Fig. 3. Northern blot hybridizations of cDNAs Q (first panel), I (second panel), Z1 (third panel), and PaB1 (fourth panel) with RNAs extracted from healthy periwinkle plants (lane 1) or periwinkle plants infected by aster yellows phytoplasma (lane 2), Spiroplasma citri (lane 3), Candidatus Liberibacter sp. (lane 4), apple proliferation phytoplasma (lane 5), stolbur phytoplasma (lane 6), or Candidatus Phytoplasma aurantifolia (lane 7).

Table 3. Outline of the experiment illustrated in Figure 5

\begin{tabular}{lcccc}
\hline \multirow{2}{*}{$\begin{array}{l}\text { Sampling for Northern blots } \\
\text { days after insect addition }\end{array}$} & \multicolumn{2}{c}{ GII 3 } & & \multicolumn{2}{c}{ GMT 553 } \\
\cline { 2 - 3 } \cline { 5 - 5 } Lanes on Northern blots & Symptoms & Lanes on Northern blots & Symptoms \\
\hline Day (D) +12 & 1 & None & $1^{\prime}$ & No \\
D +22 & 2 & Faint & $2^{\prime}$ & No \\
D +32 & 3 & + & $3^{\prime}$ & No \\
D +39 & 4 & + & $4^{\prime}$ & No \\
D +47 & 5 & ++ & $5^{\prime}$ & Faint \\
D +49 & 6 & ++ & $6^{\prime}$ & + \\
D +56 & Not done (ND) & +++ & $7^{\prime}$ & + \\
D +67 & ND & +++ & $8^{\prime}$ & + \\
D +91 & ND & +++ & $9^{\prime}$ & ++ \\
\hline
\end{tabular}


companion cells into the phloem sieve tubes (Gaurivaud et al. 2000a). Impairment of sucrose loading also is mentioned by Lepka et al. (1999) for some phytoplasmas. It was thus not surprising to find that in plants infected by certain mollicutes, there was repression of a gene involved in sugar transport (gene Q, transketolase). Our experiments comparing expression of the transketolase gene in plants infected with wild-type or 553 mutant spiroplasmas confirmed that there is a link be-

\begin{tabular}{|c|c|c|c|c|c|c|c|}
\hline & & 15 & 30 & 31 & 60 & 61 & 76 \\
\hline 1 & $t k l \subset r$ & 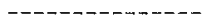 & ---------------- & 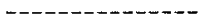 & $-\cdots-\infty-m-$ & 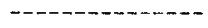 & -- \\
\hline 2 & tkIpo & 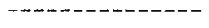 & ---- MASSSSLT & LSQVIFSFSLFRHGS & SSSSSPSLSESTESG & IKST---PFTSSHR- & ---RILPSTTVTKQQ \\
\hline 3 & proper & ------1 & 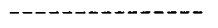 & 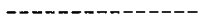 & --------- & 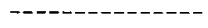 & $--a-n-n$ \\
\hline & TKLOS & 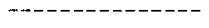 & - & 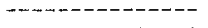 & 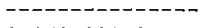 & $-\ldots-\infty-\infty-1,-\infty$ & 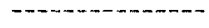 \\
\hline & $t k l \nexists t$ & ILICETYIPKVFNEL & ELQKVPPMASSAEAE & PSYIITKGGLSTD-S & CKSTSLSSSRSLVTD & LESPCLKPNNNSHSN & RRAKVCASLAEKGEY \\
\hline & & 105 & 120 & 121 & 150 & 151 & 166 \\
\hline 1 & tklcr & $\cdots \cdots-M A R K T T L I A$ & EPELVSKSVNTTRE' & 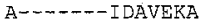 & KSGHPGMPMGCAPMG & HVLYDEEMRENPKNP & YWEN--RDRFVISAG \\
\hline & $t k l p o$ & ESVRASAAVETLEKT & DAAIVEKSVNT IRE' & A------IDAVEKA & NSGHPGLEMGCAPMG & HIIYDEVMKYNPKNP & YWEN--RDRFVISAG \\
\hline & proper & HGGRG - - - NS INY & PIHMKNLSLQELQQL & ADELREEIVYSVAKT & -GGHLSSSLGVAELT & VALH-D & HVEETRNDKIIWDV \\
\hline 4 & TKLOS & $----------N Y$ & PIHMKNL SLKELQQI & DVI FHVSKT & -GGHLGSSLGVVELT & VALH- & YVENTRQDEKILWDVG \\
\hline 5 & tkıAt & YSNRPPTFLLDTINY & RIHMKNLSVKELKQL & SDELRSDVIFNVSKT & -GGHLGSSLGVVELT & VALH-D-n- & YIENTPQDKILWDVG \\
\hline & & 181 & 210 & 225 & 240 & 241 & 256 \\
\hline 1 & tklcr & EGGCMLQYALLHLSGY & DSVKEEDLKSLRQWG & SETPAHPENFETPGV & EVTTGELGQGIASAV & GLAVAEKHLAARYNK & PGEEIVDHYTYVI \\
\hline 2 & tklpo & HGCMLQYALLHLAGY & DSVQEDDLKSERQWG & SRIPGHPENEETPGV & EVTTGPLGGGIANAV & GLAVAEKHLAARENK & FDAEIVDHYTYVILG \\
\hline 3 & proper & H---QTYGHKILTG- & ---RRSKMHTMRQTC & G-LAGF $\underline{\text { KRDESSAHD }}$ & AFGVGHSSTSISAGL & GMAIG-RDLLGKKNH & $\cdots \cdots-\cdots$ VITVI \\
\hline 4 & TKLOS & H---OSYYPHKILTE- & $\rightarrow-\rightarrow$ RRDKMPTMRQTN & G-ISGFTKRSESEYD & SEGTGHSSTTISAAL & GMAVG-RDLKGGKNN & -- VVAVI \\
\hline & tklat & $\mathrm{H}^{---Q S Y}$ PHKI LTG- & ---RRGKMPTMRQTN & G-LSGETKRGESEHD & CRGTGHSSTTISAGL & GMAIG-RDLKGKNNN & - \\
\hline
\end{tabular}

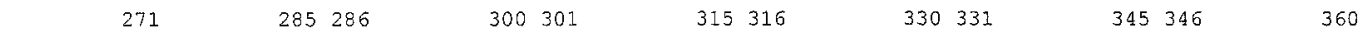

1 tklcr DGCQMEGVSNEACSI AREWGLGKLIALYDD NHITIDGDT-

2 tKLPO DGCQMEGISNEVCSI AGHWGLGKLIAFYDD NHISIDGDT-

3 proper DGAMTAGQPYHAMNN AGYLDSNLIIILNDN KOVSLPTATIDGPAP PTGAISNALTRLQSS RKFRHFGRLQK-IEK QLGGQVHEMAAKVDT

4 TKLOS DGAMTAGQAYEAMN AGYLDSDNIVILNDN KOVSLPTATLDGPAR PVGATSSALSKLOSS RPLRELREVAKGVTK QIGGSVHELAAKVDE

5 tkLAt DGAMTAGQAYEAMNN AGYLDSDMTVILNDN R OVSLPTATLDGPSP PVGALSSALSRLQSN PALRELREVAKGMTK QIGGPMHQVAAKVDV ThDp binding motif
361
375376
390391
405406
$420 \quad 421$
435436
450

1 tkler DKR-.......-.-.-FD ALGWHVIWVKNGNDG CDEIRAATEEAKSVK DR-PTMIKVTTTIGY GAP-SKANTYGVHGN ALGPKEAEATRKNLG

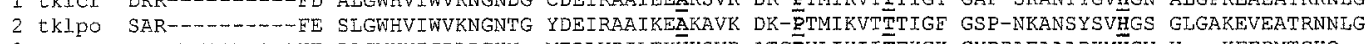

3 proper YMRGMNSQRAS-LFE DLGMYYIGPLDGHN- MEDLVDILEKVTKSVP ATGPVLIHIITEKGK GYPPAEAAADKMHGV V--KFEPMTGKQ-

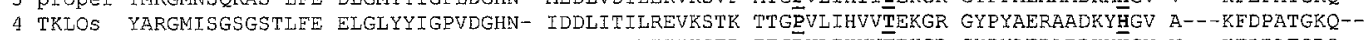

5 tkLAt YARGMISGTGSSLFE ELGLYYIGPVDGHN- IDDT,VAILKEVKSTR TTGPVLIHVVTEEKGR GYPYAERADDKYHGGV V---KFDPATGRQ--
451
$465 \quad 466$
$480 \quad 481$
495496
510511
525526
540

I tKICK WPYEPFHVPDDVKKH WSRHIAEGRALESAW NAKFAEFQKKEPEEA ADLKSIITGELPTNW ESIFPTYTPENPGLP TRTLSHOILNGLGDV

2 tkIPO WPYEPEHVPEDVKSH WSRHTPEGAALETEW NAKFAEYEKKYAEEA ADLKSIITGELPAGW EKALPTYTPESPADA TRNLSQQNLNALAKV

3 proper ----EKSKSKTKSY - $-\cdots$

4 TKLOS --.-EKSPAKTLSY -...

5 tkIAT -- --EKTTNETQSY - -

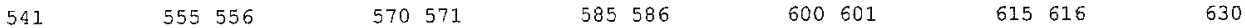

$1 \mathrm{tklCr}$ LPGLLGGSADLTLSN MAFLKNSGDFOKKSF GERNVKFGAREHAMG SICNGLALHSPGLLP YCATY-FVETDYMR AAMRISALSKARVLY

2 tklpo LPGELGGSADIASSN MTLLKMEGDFOKNTP EERNLREGVREHGMG AICNGIALHSLGLIP YCATE-T-FVFDYMR GAMRISALSERGVIY

3 proper IHAAMGGGTGLNL-- -.-..-FOKHEF -ERCFDVGIAEQHAV TFAAGLA--SEGLKP FCAIYSSELLQRGYDQ VVHDVD-LQKIPVRF

4 TKLOS IHAAMGGGTGLNY-- -......-FLRREF -NRCFDVGIAEQHAV TFAAGLA--CEGLKP FCAIYSSELQRGYDQ VVHDVD-IQKLPVRF

5 tkiAt IHAAMGGGTGLNL-- --_-_-FQRRE -TRCFDVGIAEQHAV TEAAGLA--CEGLKR FCAIYSSFMQRAYDQ WVHDVD-IQKLPVRF

$\begin{array}{lllllll}631 & 645646 & 660661 & 675676 & 690691 & 705706\end{array}$

1 tklcr IMTHDSIGL-GEDGP THQPVEHLASFRAMP NILTLRPADGNETAG AYRAAVONGERPSIL VLAROKLPQLPGTSI EGVSKGGYVISDNSR

2 tk1po vMTHDSIGL-GEDGP THQRIEHLASFRAMP NILMERPADGNETAG AYKVAVLKRKTPSIL ALSR̊OKLPQLAGTSI EGRAKGGYIVSDNSS

3 proper A M-DRAGLVGADGP -HCGAFDTTEMACLP NMVVMAPSDETELMH MVATAAAIDDRLVAF DIPEEM---ALVQFE HQTTKELHYRLVREE

4 TKLOS AM-DRAGLVGADGP THCGAFDVTYMACLP NMVVMAPSDEAELCH MVATAAAIDDRPSCE RYPRGN---GIGVPL PPNYKGVPLEVGKGR.

5 tkIAT A M--DRAGLVGADGP THCGAFDVTEMACLP NMIVMAPSDEADLFN MVATAVAIDDRPSCE RYPRGN---GIGVAL PPGNKGVPIEIGRGR. Transketolase motif

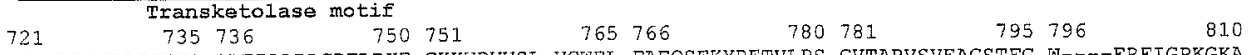

1 tklCr GGNSKPDVILIGTGS ELEIAARAGDELRKE GKKVRVVSL-VCWEL FAEQSEKYRETVIRS GVTARVSVEAGSTFG W--.-ERFTGPKGKA

2 tKlpo G-NKPDVILIGTGS ELEIAVKAAEEIKKE GKTVRVVSF-VCWEL YDEQSAEYKESVLPS SVTARVSIEAGSTFG W----QKEVGDKGKA

3 proper YCWR-ERVAILGYGA MVQNCLMAAQLIEIN GISATVVDARFCKPL --DGDLIRK--DAQ QHEVLITVEEGSIGG FGSHVAQFLALNGLI

4 TKLOS VLLEGERVALLGYGS AVQYCLAAASLVERH GLKVTVADARFCKPL --DQTLIRR---LAS SHEVLLTVEEGSIGG FGSHVAQFMALDGLI

5 tklAt. ILKEGERVALLGYGS AVQSCLGAAVMLEER GLNVTVADARFCKPL --DRALIRS---LAK SHEVLITVEEGSIGG FGSHVVQFLALDGLI

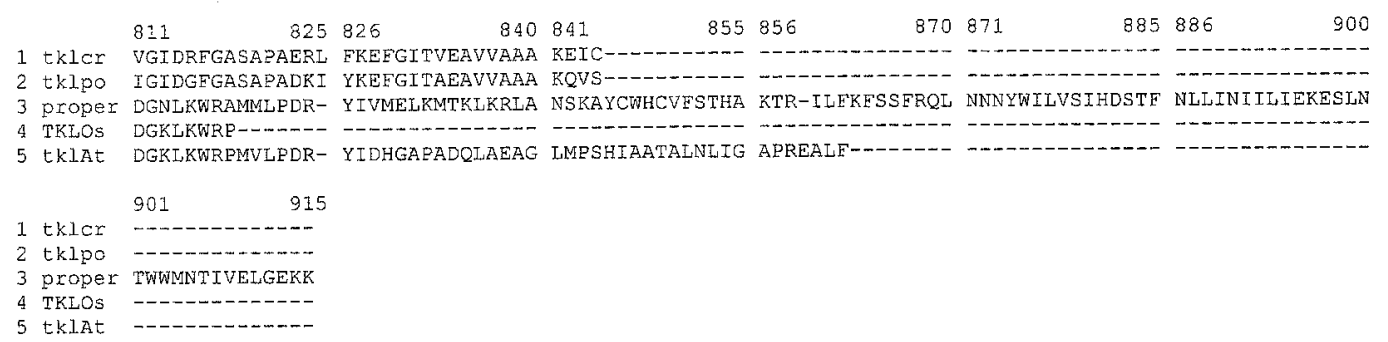

Fig. 4. Amino acid comparisons of the deduced protein product of gene $\mathrm{Q}$ with transketolase or transketolase-like protein sequences from databanks. tklcr $=$ transketolase from Craterostigma plantagineum (Z46648); tklpo = transketolase from Solanum tuberosum (Z50099); proper = protein product of Q fragment of Catharanthus roseus; tklos = transketolase-like protein from Oriza sativa $(\mathrm{AF024512)}$; tklat $=$ transketolase from Arabidopsis thaliana (Y14333). Underlined amino acids indicate invariant residues; areas surrounded by black lines indicate a thiamin pyrophosphate binding motif and a transketolase motif. 
tween fructose utilization by the spiroplasma and deregulation of transketolase expression. Interestingly, in A. thaliana, mutation of the transketolase gene causes a highly pleiotropic phenotype affecting the expression of several photosynthetic genes and pigment production (albino phenotype). In general, albino phenotypes are the result of a blockage in the photosynthetic process, affecting chloroplast development either directly or indirectly, and photosynthetic genes are regulated by carbohydrates (Mandel et al. 1996). Inhibition of the transketolase gene might therefore be responsible for the repression of the genes involved in photosynthesis (C2, Z1, G17-4). Indeed, we showed that $\mathrm{Z} 1$ followed the same inhibition pattern as gene $Q$ in plants infected with various bacteria and showing yellowing symptoms. Such deregulations explain the leaf's yellow symptoms induced by $S$. citri, the stolbur phytoplasma, and other phloem-restricted agents but not the proliferations induced by several other phytoplasmas. It also is speculated that growth aberrations induced by phloemrestricted bacteria could be the result of perturbations in the plant hormonal balance (Chang 1998). Gene I coding for a putative sterol C-methyl transferase, an enzyme involved in phytosterol biosynthesis, can play such a role. Indeed, sterols are structural membrane components as well as precursors of steroid growth regulators (Haughan et al. 1988; Shi et al. 1996). This gene is down regulated in S. citri, stolbur phytoplasma, and liberibacter infections, all characterized by stunting and internode shortening.

This work represents the first identification of plant genes that are deregulated following infection by mollicutes. More work has to be carried out to identify the metabolic pathways modified during plant-mollicute interactions. The genes deregulated during early stages of plant-mollicute interactions also are yet to be identified. The development of expressed sequence tags (EST) on high-density filters for plants such as tomato, a host for the stolbur phytoplasma, and celery, a host for stolbur and $S$. citri, will allow in the near future a more complete analysis of the plant response to mollicute infections. The genes that we isolated will be useful as markers of infection and as controls for the EST filters.
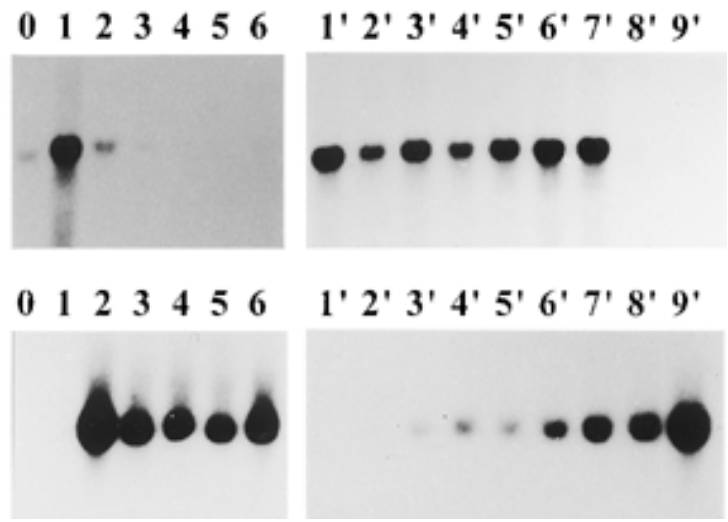

Fig. 5. A, Northern blot hybridizations with transketolase or B, spiralin genes with RNAs extracted from healthy periwinkle plants (lane 0) or periwinkle plants infected with Spiroplasma citri GII3 wild-type (lanes 1 to 6) or $S$. citri mutant GMT 553 (lanes $1^{\prime}$ to $9^{\prime}$ ).

\section{ACKNOWLEDGMENTS}

We gratefully acknowledge P. Bonnet and J. B. Reynaud for growing plants and insects. This work was financially supported by a grant from AIP Microbiologie INRA (P00188).

\section{LITERATURE CITED}

Benito, E. P., Prins, T., and Van Kan, J. A. 1996. Application of differential display RT-PCR to the analysis of gene expression in a plantfungus interaction. Plant Mol. Biol. 32:947-957.

Bernacchia, G., Schwall, G., Lottspeich, F., Salamini, F., and Bartels, D. 1995. The transketolase gene family of the resurrection plant $\mathrm{Cra}$ terostigma plantagineum: Differential expression during the rehydration phase. EMBO J. 14:610-618.

Bové, J. M., and Garnier, M. 1998. Walled and wall-less eubacteria from plants: Sieve-tube-restricted plant pathogens and plant surface contaminants. Pages 7-16 in: Plant Cell, Tissue and Organ Culture, Vol. 52. Kluwer Academic Publishers, Dordrecht, The Netherlands.

Bové, J. M., Foissac, X., and Saillard, C. 1993. Spiralins. Subcell. Biochem. 20:203-223.

Chang, C.-J. 1998. Pathogenicity of aster yellows phytoplasma and Spiroplasma citri on periwinkle. Phytopathology 88:1347-1350.

Falconet, D., Godon, C., White, M. J., and Thompson, W. F. 1993. Sequence of 1 hcb $3 * 1$, a gene encoding a phosphosystem II chlorophyll a/b-binding protein in Pisum. Biochim. Biophys. Acta 1173:333-336.

Foissac, X., Danet, J. L., Saillard, C., Gaurivaud, P., Laigret, F., Paré, C., and Bové, J. M. 1997. Mutagenesis by insertion of Tn4001 into the genome of Spiroplasma citri: Characterization of mutants affected in plant pathogenicity and transmission to the plant by the leafhopper vector Circulifer haematoceps. Mol. Plant-Microbe Interact. 10:454461.

Fos, A., Danet, J. L., Zreik, L., Garnier, M., and Bové, J. M. 1992. Use of a monoclonal antibody to detect the stolbur mycoplasmalike organism in plants and insects and to identify a vector in France. Plant Dis. 76:1092-1096.

Garnier, M., Zreik, L., and Bové, J. M. 1991. Witches' broom, a lethal mycoplasmal disease of lime trees in the Sultanate of Oman and the United Arab Emirates. Plant Dis. 75:546-551.

Garivaud, P., Danet, J.-L., Laigret, F., Garnier, M., and Bové, J. M. 2000a. Fructose utilization and phytopathogenicity of Spiroplasma citri. Mol. Plant-Microbe Interact. 13:1145-1155.

Gaurivaud, P., Laigret, F. Garnier, M., and Bové, J. M. 2000b. Fructose utilization and pathogenicity of Spiroplasma citri: Characterization of the fructose operon. Gene 252:61-69.

Haughan, P. A., Lenton, J. R., and Goad, L. J. 1988. Sterol requirements and paclobutrazol inhibition of a celery cell culture. Phytochemistry 27:2491-2500.

He, Z. H., Cheesman, I., He, H. Z., and Kohorn, B. D. 1999. A cluster of five cell wall-associated receptor kinase genes, Wak 1-5 are expressed in specific organs of Arabidopsis. Plant Mol. Biol. 39:1189-1196.

Jagoueix, S., Bové, J. M., and Garnier, M. 1994. The phloem-limited bacterium of greening disease of citrus is a member of the $\alpha$ subdivision of the proteobacteria. Int. J. Syst. Bacteriol. 44 :379-386.

Lange, M. B., Wildung, M. R., McCaskill, D., and Croteau, R. 1998. A family of transketolases that directs isoprenoid biosynthesis via a mevalonate-independent pathway. Proc. Natl. Acad. Sci. USA 95:21002104.

Lepka, P. Stitt, M., Moll, E., and Seemüller, E. 1999. Effect of phytoplasmal infection on concentration and translocation of carbohydrates and amino acids in periwinkle and tobacco. Physiol. Mol. Plant Pathol. 55:59-68.

Liang, P., and Pardee, B. A. 1992. Differential display of eukaryotic messenger RNA by means of the polymerase chain reaction. Science 257:967-971.

Maitra, N., and Cushman, J. C. 1994. Isolation and characterization of a drought-induced soybean cDNA encoding a D95 family lateembryogenesis-abundant protein. Plant Physiol. 106:805-806.

Mandel, M. A., Feldmann, K. A., Herrera-Estrella, L., Rocha-Sosa, M., and Leon, P. 1996. CLA1, a novel gene required for chloroplast development, is highly conserved in evolution. Plant J. 9:649-658.

Mareyrat, F., Moouzeyar, S., Nicolas, P., Tourvieille de Labbrouhe, D., and Ledoigt, G. 1998. Cloning, sequence and characterization of a 
sunflower (Helianthus annuus L.) pathogen-induced gene showing sequence homology with auxin-induced genes from plants. Plant Mol. Biol. 38:899-903.

McCoy, R. E. 1979. Mycoplasmas and yellows diseases. Pages 229-264 in: The Mycoplasmas, Vol. III: Plant and Insect Mycoplasmas. R. F. Whitcomb and J. G. Tully, eds. Academic Press, New York.

McCoy, R. E., Caudwell, A., Chang, C. J., Chen, T. A., Chiykowski, L. N., Cousin, M. T., Dale, J. L., De Leeuw, G. T. N., Golino, D. A., Hackett, K. J., Kirkpatrick, B. C., Marwitz, R., Petzold, H., Sinha, R. C., Sugiura, M., Whitcomb, R. F., Yang, I. L., Zhu, B. M., and Seemüller, E. 1989. Plant diseases associated with mycoplasma-like organisms. Pages 545-640 in: The Mycoplasmas, Vol. 5: Spiroplasmas, Acholeplasmas, and Mycoplasmas of Plants and Arthropods. R. F. Whitcomb and J. G. Tully, eds. Academic Press, New York.

Puissant, C., and Houdeline, L.-M., 1990. An improvement of the single step method of RNA isolation by acid guanidinium thiocyanatephenol-chloroform extraction. Biotechniques 8:148-149.

Renaudin, J., and Bové, J. M. 1995. Plasmid and viral vectors for gene cloning and expression in Spiroplasma citri. Pages 167-178 in: Molecular and Diagnostic Procedures in Mycoplasmology, Vol. 1. J. G. Tully and S. Razin, eds. Academic Press, New York.

Saglio, P., Laflèche, D., Bonissol, C., and Bové, J. M. 1971. Isolement, culture et observation au microscope électronique des structures de type mycoplasme associées à la maladie du stubborn des agrumes et leur comparaison avec les structures observées dans le cas de la maladie du greening des agrumes. Physiol. Veg. 9:569-582.

Saglio, P., Lhospital, M., Laflèche, D., Dupont, G., Bové, J. M., Tully, J. G., and Freundt, E. A. 1973. Spiroplasma citri gen. and sp. nov.: A mycoplasma-like organism associated with Stubborn disease of citrus.
Int. J. Syst. Bacteriol. 23:191-204.

Schenk, G., Layfield, R., Candy, J. M., Duggleby, R. G., and Nixon, P. F. 1997. Molecular evolutionary analysis of the thiamine-diphosphatedependent enzyme, transketolase. J. Mol. Evol. 44:552-572.

Seehaus, K., and Tenhaken, R. 1998. Cloning of genes by mRNA differential display induced during the hypersensitive reaction of soybean after inoculation with Pseudomonas syringae pv. glycinea. Plant Mol. Biol. 38:1225-1234.

Seemüller, E., Marcone, C., Lauer, U., Ragozzino, A., and Göschl, M. 1998. Current status of molecular classification of the phytoplasmas. J. Plant Pathol. 80:3-26.

Shi, J., Gonzales, R. A., and Bhattacharyya, M. K. 1996. Identification and characterization of an S-adenosyl-L-methionine: Delta24-sterolC-methyltransferase cDNA from soybean. J. Biol. Chem. 271:93849389.

Smart, C. D., and Kirpatrick, B. C. 1996. Identification of host plant genes whose expression is altered upon aster yellows phytoplasma infection. (Abstr.) IOM Lett., 4:274-275.

Truesdell, G. M., and Dickman, M. B. 1997. Isolation of pathogen/stress-inducible cDNAs from alfalfa by mRNA differential display. Plant Mol. Biol. 33:737-743.

Ye, F., Renaudin, J., Bové, J. M., and Laigret, F. 1994. Cloning and sequencing of the replication origin (ori C) of the Spiroplasma citri chromosome and construction of autonomously replicating artificial plasmids. Curr. Microbiol. 29:23-29.

Zreik, L., Carle, P., Bové, J. M. and Garnier, M. 1995. Characterization of the mycoplasmalike organism associated with witches' broom disease of lime and proposition of a Candidatus taxon for the organism, Candidatus phytoplasma aurantifolia. Int. J. Syst. Bacteriol. 45:449-453. 